\title{
ACRL Joint Committee Activities
}

The Association of College and Research Libraries represents the interests of libraries and librarians in postsecondary education on four joint committees with other educational associations. Each of the four committees met during the spring of 1973.

The Joint Committee on Junior College Libraries (American Association of Community and Junior Colleges, Association for Educational Communications and Technology, and ACRL) met on February 28, during the annual conference of AACJC, in Anaheim, California. The chairman, representing ACRL, is Hal C. Stone, coordinator of the Library and Learning Resources Center of Los Angeles City College. Other ACRL representatives are Joleen Bock, William J. Hoffman, and Michael P. Schuller. The committee is assembling a visual presentation of the "Guidelines for Two-Year College Learning Resources Programs" (CRL News, Dec. 1972) to illustrate the variety of administrative models supported by the guidelines. The pilot will be previewed during the program meeting of ACRL's Junior College Libraries Section at the ALA conference in Las Vegas. The committee is also developing forms and procedures for revising the guidelines. To reflect the current terminology in the two-year college field, the committee elected to change its name to "Joint Committee on Learning Resources Programs."

The Joint Committee on College Libraries (Association of American Colleges, American Association of University Professors, and ACRL) met in Washington, D.C., on March 25. The chairman, representing AAUP, is Martha Friedman, professor at the University of Illinois at Urbana-Champaign. The ACRL representatives are Brendan Connolly, Wyman Parker, and Luella R. Pollock. The committee heard a report from $\mathrm{AAC}$ on the recent decision of the AAC Commission on Liberal Learning to recommend approval of the "Joint Statement on Faculty Status of College and University Librarians" (CRL News, Sept. 1972) with an appended interpretation relating to procedures for implementation. As the principal item of business, the committee reviewed a proposal for improving the role of the college library in response to new demands on higher education. A revised draft of the proposal will be presented to each of the respective associations in June,

The Joint Committee on University Extension Library Services (National University Extension Association and ACRL) met in Omaha,
Nebraska, on April 15, during the annual conference of NUEA. The chairman, representing NUEA, is Frank MacDougall, librarian of the Continuing Education Library at Michigan State University. The ACRL representatives are Barry E. Booth, Karl S. Bynoe, Nina Cohen, and Dorothy A. Kittel. The committee drafted the following resolution, which was subsequently passed at the NUEA annual association business meeting on April 18:

WHEREAS, There is a continuing public need for a variety of extension programs in postsecondary education from our colleges and universities; and

WHEREAS, The concept of continuing education has now become so comprehensive as to include a broad spectrum of collective and individual learning experiences; and

WHEREAS, The nation's libraries constitute a network of major resources in the support of these learning experiences; be it therefore

RESOLVED, That the National University Extension Association and the Association of College and Research Libraries (a division of the American Library Association) make a concerted effort to devise new uses of libraries as facilities for formal and continuing education services, examine the capabilities of increased interlibrary cooperation among university, state, public and other types of libraries as a system for better utilization of existing educational resources, and aggressively seek public and private funds to strengthen and expand the American tradition of lifelong education.

To reflect the changing nature of extension services, the committee is considering revisions of the "Guidelines for Library Services to Extension Students" (ALA Bulletin, Jan, 1967) and other materials.

The Joint Committee on University Library Standards (Association of Research Libraries and ACRL) met during the ALA Midwinter Meeting in Washington, D.C., and during the ARL, spring meeting in New Orleans. Robert B. Downs, dean of library administration emeritus of the University of Illinois, is chairman; John W. Heussman, director of the University Library at the University of Nebraska, is vicechairman. The ACRL representatives are Gustave A. Harrer, John P. McDonald, Ellsworth G. Mason, and Norman E. Tanis. Methods for developing a standards statement and various forms of standards statements are under consideration by the committee. 
Take this opportunity to receive the best books published by the American Library Association at a saving of $40 \%$ or $50 \%$ off listed prices. For the first time in its

existence, the ALA is offering these recent quality books to you at $40 \%$ off on BILLED orders; $50 \%$ off on PREPAID orders; COUPON ON NEXT PAGE.

Unless otherwise indicated, all books have cloth binding. MINIMUM ORDER $\$ 5.00$ This sale runs from May 1, 1973 to Sept. 1, 1973

3005-0 Accese to Public Librarles: A Pesearch Prolect. International Research Associates, Inc. Paper \$3.00.

A survey of restrictions on free and equal access to the resources and services of public libraries.

0079-8 American and Britioh Genealogy and Heraldry: A Selected Llet of Books. P. William Filby compiler. $\$ 10.00$.

Over 1,800 entries list the best and the best-known warks in genealogy and heraldry

0117-4 American Film Inatltute' Guide to College Film Courees, 1971-1972. Dorothy I. Weil, editor. Published for the American Film Institute by ALA Paper \$3.50.

Lists 427 colleges and universities oflering credit courses in film.

American Library Lawa, 3d ed. Alex Ladenson 0006-2 First Supplement 1963-64 \$5.50; 0007-0 SeCond Supplement 1965-66 \$6.00; 0068-2 Third Supple ment 1967-68 \$6.50; 0106-9 Fourth Supplement 1969-70 \$6.50.

Compilation of federal and state laws affecting libraries.

0014-3 Bibliography of Place-Name Lilerature: Uniled States and Canada, 2d ad. Aichard B. Sealock and Pauline A. Seely, compilers. $\$ 7.50$.

Revised and enlarged edition of the authors' standard guide (1948) to the literature dealing with place names in the U.S. and Canada.

3012-3 Biographical Directory of Librarians in the Field of Slavic and East European Sludies. Peter A. Goy, compiler and editor. Paper \$3.25.

Identilies more than 300 librarians, information specialists, archivists, bibliographers, and editors who have subject of language compelence in the Slavic and East European fields.

0084-4 A Biographical Directory of Librarians in the United States and Canada, 5th ed. Lee Ash, editor $\$ 45.00$.

Contains biographies of approximately $20,000 \quad \mathrm{li}-$ brarians, archivists, and information scientists

Books for Children: 0016-X 1960-65 \$10.00: 0017-8 1965-66 paper \$2.00; 0018-6 1966-67 paper $\$ 2.25$ 0019-4 1967-68 paper \$3.00; 0082-8 1968-69 paper $\$ 3.50$.

Annual compilations listing titles selected and recommended for purchase in Children's Books sec. tion of The Booklis!.

0070-4 Bridge of Children' Booke. Jella Lepman. $\$ 5.00$.

Jella Lepman's story of the restoration of Germany by using children's books.

3086-7 Buckram Syndrome: A Crilical Esay on Paperbacks in Public Libraries of the Uniled Slates. Public Library Reporter No. 13. Marie T. Curley. Paper $\$ 1.75$.

Public library use of paperbacks is explored.

3114-6 Case for Faculiy Slatus for Academic Librarians. ACAL Monograph No 33. Lewis C. Branscomb, editor. Paper $\$ 5.00$

Contains 13 papers in lavor of faculty status for librarians

0023-2 Cataloging of Persian Works: Including Rules of Transliteration, Entry, and Description. Nasser Sharify. $\$ 3.50$

A comprehensive code for cataloging Persianlanguage publications based on accepted American principles of cataloging.
0025-9 Claselficallon: An Introductory Manual, 2d ed. Margaret $M$. Herdman. Paper $\$ 1.00$

An elementary and compact study of classification 3021-2 College Teaching and the College Library. ACRL Monograph No. 23. Patricia B. Knapp. Paper $\$ 3.00$

An examination of library use by students at Knox College and the relationship between college teach ing and student use of the library.

0030-5 Firal Freedom: Liberty and Justice in the World of Books and Reading. Robert B. Downs, editor. $\$ 8.50$

A compilation of 88 outstanding twentieth-century American and British writings on Iiterary censorship and intellectual freedom.

3122-7 Format Aecognition Process for MAPC Pec ords: A Logical Design. Information Systems Office Library of Congress. Paper $\$ 10.00$

Format recognition is a technique designed for the computer analysis of bibliographic records

3098-0 German Exile Literature in America 1933-

1950: A Hislory of the Free German Press and Book Trade. Robert E. Cazden. \$10.00.

This pioneering bibliographical study illuminates an important chapter in the history of German-American cultural interchange-the years 1933 10 1950.

0032-1 Gulda lo Japanese Relerence Books: Nihon no Sankolonho, 1965 Revised Edition. Edited and Translated by the international House Library, English Edition. $\$ 10.00$

The Japanese counterpart of Wincheli's Guide to Aeterence Books edited and translated for those who do not read Japanese

0033-X Gulde to Lisls of Master Theses. Dorothy $M$ Black, compiles. $\$ 5.25$.

A compilation, through 1964, of all known bibliographies, collections of abstracts, and lists of U.S. and Canadien master's theses.

0080-1 Intifutional Library Services: A Plan for the State of Illinois. Social Educational Research and Development, Inc. Paper \$3.50.

Analyzes the existing library lacilities, services and programs in Illinois state institutions.

0040-2 Integrating Library Instruction with Clasaroom Teaching at Plainview Junior High School. Elsa Berner. Paper $\$ 2.75$.

Uses a composite, hypothetical school to show a school-wide library program based on teacher-library cooperation.

0085-2 Japan and Korea: An Annotated Bibliography of Doctoral Disserfations in Weslern Languages, 1877-1969. Compiled and edited by Frank J. Shulman for the Center for Japanese Studies. The University of Michigan. Paper \$6.95.

This work assembles in classitied order approximately 2,500 dissertations from 26 countries and written in 14 Western languages, that bear on Japan and Korea.

3104-9 Library-Sponsored Discussion Group. Robert Lee. Paper $\$ 1.75$.

Methods of planning and organizing an effective adult education program based on having group discussion in the public library.

3101-4 Library US A: A Blbliographle and Descriplive Report. Gordon P. Martin, Joseph Becker, and Alphonse F. Trezza. $\$ 5.00$

Report on the American Library Association ex hibit at the 1964-65 New York World's Fair. 
The Llterature of Jaxz. Donald Kennington. 0102-6 Cloth \$6.95. 0105-0 Paper \$3.50.

No aspect of Jazz is neglected from this reliable and selective bibliography.

3095-6 Melropolilan Llbraries: The Challenge and the Promiee. Judith Dommu Guthman. Paper \$1.75.

Inner-city library programs are reviewed and necessary legislative actions recommended.

3050-6 Natlonal Invenlory of Library Neede. American Library Association. Paper \$2.00.

Details the gap between library resources on a national basis and ALA's minimum standards for library service in the areas of staff, operating expenditures, and book collections.

3059-X Planning Library Buildings for Service: Proceeding of a Library Bullding and Equipment Inall. tute, July 6-8, 1961. Sponsored by the Library Administration Division, ALA. Harold L. Roth, editar. Paper $\$ 3.75$.

Covers the design and layout of public, school. college, and university libraries with emphasis on service 10 users.

3061.1 Present Status and Future Praspecte of Peierence/Informatlon Service: Proceedinge of the Conference Hald al The School of Library Servlce, Columbia Universily, March 30 -April 1, 1966. Winifred $\mathrm{B}$. Linderman, editor. Paper $\$ 3.75$

Analyzes the fundamental aspects of reference/ information service, consumers of information, services offered, information networks, sources of information, and development and use of storage and retrieval systems.

3062-X The Printed Book Catalogue in Amerlcan Librarien: 1723-1900. ACRL Monograph No. 26. Jim Aanz. Paper $\$ 3.00$.

First documented history of the printed public or reader catalog.

0049-6 Promollon Jdena for Publlc Librarles. Sarah L. Wallace. Paper $\$ 2.00$

Workable ideas on how to dramatize the work and services of the library and stimulate interest in them. 3065-4 Public Library Pollcies-General and Speciflc. Public Library Reporter No. 9. Ruth M. White, editor Paper \$3.50.

Selected policy statements in actual use by 200 public libraries of various sizes which provide a useful guide for libraries and irustees formulating policy statements.

3087-5 Public Library Systems In the United States: A Survey of Multijurisdictional Systems. Nelson As sociates for the Public Library Association, ALA $\$ 10.00$.
Landmark study based on data collected from 58 selected systems

3067-0 Realizalion: The Final Report of the Knapp School Libraries Project. Peggy Sullivan, editor. $\$ 10.00$.

Aeports on each of the eight schools and teachereducation programs which participated in the Knapp Project as demonstrations of excellent school library programs, $1963-68$

3069-7 Scientilic Serials: Characleristlcs and LIata of Most Cited Publications in Mathematica, Physlca, Chemistry, Geology, Physiology, Botany, Zoology and Entomology. ACRL Monograph No. 16. Charles Harvey Brown. $\$ 5.00$.

Reviews the technique of citation analysis on which this book is based.

0086-0 Serial Publications in the British Parliamentary Papers, 1900-1968: A Elbliography. Frank Rod gers $\$ 7.50$.

Identifies and lists by responsible agency those serials that have appeared in the House of Commons Sessional Papers between 1900 and 1968 .

3075-1 Studenl Use of Libraries: An Inquiry into the Needs of Students, Libraries, and the Educationa Process. Papers of the Conference within a Conference. Paper $\$ 3.00$

Presents ways of meeting increased student demand for library services.

0056-9 Subject Guide to Major Uniled States Gov-rnmeni Publications. Ellen Jackson. \$5.50.

This comprehensive, selective subject guide to U.S. Government publications of major and lasting interest covers titles of permanent importance from the earliest period to early 1967

Subscription Books Bulletin Revlewa: 0061-5 1962-64 paper, \$2.00; 0062-3 1964-66 paper, \$2.25; 0063-1 $1966-68$ paper, $\$ 2.25$.

Reviews of reference works originally published in The Booklist.

3097-2 Undergraduate Library: ACAL Monograph No 31. Irene A. Braden. Paper \$8.50.

Analyzes the purpose of the first six undergraduate libraries in the country.

3111-1 University and Research Libraries in Japan and the United Stales. Thomas R. Buckman, Yukihisa Suzuki, and Warren Tsuneishi, editors. $\$ 13.50$.

Contributions by 44 American and Japanese IIbrarians, educators and scholars in an exchange of information on the development of professiona activities, professional associations, libraries and advanced information systems in their respective countries.

AMERICAN LIBRARY ASSOCIATION - 50 East Huron St. Chicago, Illinois 60611

Please send the WAREHOUSE SALE books in the quantities indicated below:

Date

\begin{tabular}{|c|c|c|c|}
\hline 1005-0 & $\$ 3.00$ & $-0016-X$ & 10.00 \\
\hline 0079-8 & 10.00 & -0017-8 & 2.00 \\
\hline $117-4$ & 3.50 & -0018-6 & 2.25 \\
\hline 106-2 & 5.50 & 0019-4 & \\
\hline $07-0$ & 6.00 & -0082-8 & \\
\hline $68-2$ & 6.50 & $0070-4$ & \\
\hline-9 & 6.50 & _ $3086-7$ & \\
\hline & 7.50 & __ $3114-6$ & \\
\hline & 3.25 & .0023-2 & \\
\hline & 45.00 & $-0025-9$ & \\
\hline
\end{tabular}

TOTAL LIST PRICE

LESS $40 \%$, BILL FOR

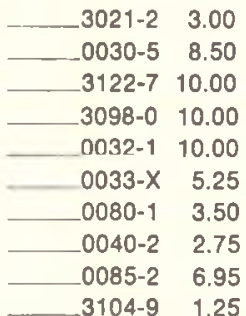

$3104-9 \quad 1.25$
$3101-4 \quad 5.00$

0102-6 6.95

$0105-0 \quad 3.50$

$3095-6 \quad 1.75$

$3050-6 \quad 2.00$

$3059-\times \quad 3.75$

$3061-1 \quad 3.75$

$3062-x \quad 3.00$

0049-6 2.00

$3065-4 \quad 3.50$
/ LESS $50 \%$

Bill to

3087-5 10.00

3067-0 10.00

$3069-7 \quad 5.00$

0086-0 7.50

$3075-1 \quad 3.00$

0056-9 5.50

$0061-5 \quad 2.00$

0062-3 2.25

$0063-1 \quad 2.25$

$3097-2 \quad 8.50$

$3111-1 \quad 13.50$

Ship to

Name 